$\begin{array}{ll}\text { Research Square } & \begin{array}{l}\text { Preprints are preliminary reports that have not undergone peer review. } \\ \text { They should not be considered conclusive, used to inform clinical practice, } \\ \text { or referenced by the media as validated information. }\end{array}\end{array}$

\title{
A Questionnaire-Based Survey to Assess the Timing of Intubation in COVID-19 Pneumonia.
}

\section{Samir Samal}

Siksha O Anusandhan University Insitute of Medical Science and SUM Hospital

Shakti Bedanta Mishra ( $\nabla$ shaktimishra84@gmail.com )

Siksha 0 Anusandhan University Institute of Medical Sciences and SUM Hospital

\section{E Shantanu Kumar Patra}

Siksha O Anusandhan University Institute of Medical Science and SUM Hospital

\section{Rajesh Kasimahanti}

Sunnybrook Health Science Centre Interdepartmental division of Critical Care MedicineUniversity of toronto

\section{Research}

Keywords: ARDS, COVID19, Pneumonia, Intubation, P-SILI

Posted Date: January 11th, 2021

DOl: https://doi.org/10.21203/rs.3.rs-141346/v1

License: (1) (1) This work is licensed under a Creative Commons Attribution 4.0 International License. Read Full License 


\section{Abstract}

\section{Background}

Many COVID19 pneumonia patients progress to Acute respiratory distress syndrome and end up in Intensive Care Units. Given that it is a novel viral infection, the progress of the disease, its management and associated outcomes are yet to be studied in detail. ARDS associated with COVID 19 is the same as before or different and the timing of intubation in such patients is a topic up for debate. This survey aimed to assess the opinion regarding management of COVID 19 ARDS and the timing of intubation in those patients.

\section{Methods}

292 clinicians including anesthesiologists, intensivists and others involved in managing COVID 19 ARDS patients at various centres were surveyed with web-based questionnaire cross sectionally within the time period of $10^{\text {th }}$ June 2020 to $31^{\text {st }}$ August 2020 after taking prior consent. Their responses were recorded and analyzed with statistical software IBM SPSS version 25.0.

\section{Results}

Among 292 included participants, 172 were intensivist, 84 were anesthesiologists and rest were others. Most of the intensivists (51.2\%) had seen more than 100 COVID 19 severe ARDS patients. Around $82 \%$ of clinicians were agreed that COVID 19 ARDS was different from another form of ARDS. $67.1 \%$ of participants were agreed with patient induced self-inflicted injury could have happened in this disease. Likewise, around $91.8 \%$ of doctors involved in managing patients were believed that HFNC could be helpful if there were falling of saturation. $37 \%$ of participants were not agreed with early intubation, which may increase the risk of mortality and nosocomial infections.

\section{Conclusions and Relevance}

There was confusion in most doctors with intubation timing even if there was an indication for intubation. These confusions may be due to non-availability of specific recommendation regarding intubation in COVID 19 severe ARDS patients. However, most of the literature recommended for early intubation in these patients when indicated.

\section{Introduction}

On March 11th, 2020 world health organization (WHO) declared COVID-19 as a pandemic.[1] Nearly 5\% of the total cases require admission in the Intensive care unit (ICU).[2] Many of these patients who get admitted in the ICU subsequently go on to require some form of mechanical ventilation. The surviving sepsis campaign issued guidelines in which they stated that the mechanical ventilatory support in COVID19 should be the same as that is being done in another acute respiratory distress syndrome (ARDS) patients.[3] 
The respiratory symptoms associated with COVID-19 have similarities with other forms of ARDS. COVID19 associated hypoxemia is postulated to be due to 2 distinct forms of lung injury. One of the forms is the classical ARDS and the other is an effect on the microvasculature of the lungs resulting the formation of dead space.[4] Being a novel viral infection and the progress and outcome of the disease yet to be studied in detail with evidence, management of patients has varied from place to place and person to person. With a sudden spurt in the number of patients being admitted to ICUs with pneumonia and ARDS, logistic factors (workforce and device availability) had to be considered while managing such patients. The pathophysiology of hypoxemia in COVID-19 is also multifactorial. All these factors taken together, there is a confusion regarding when to intubate these patients. There is a debate which is going on among the Critical Care physicians regarding the timing of intubation.

This survey was planned to assess the opinion and the practice among the critical care physicians in this aspect. The management of COVID-19 is still evolving as the pandemic progresses and we gain new insights into the pathophysiology and the management of the disease. Most of the centres that are managing COVID-19 patients are doing so, based on their institutional guidelines. This survey was planned to give us an idea regarding the Critical Care community's opinion about how to manage COVID19 patients with ARDS in ICU.

\section{Methods}

This web-based, multicenter, cross-sectional questionnaire study, was conducted over three months (June to August 2020). Institutional ethics committee clearance was obtained before the start of the study. The questionnaires were sent to physicians involved in the care of COVID-19 patients.

\section{Study Design}

The set of questions in the questionnaire was finalized by the Delphi method. Four critical care physicians were involved in the discussion and finalization of this questionnaire. The questions were selected to assess the demography, clinical experience in the management of COVID-19 patients and the opinion and practice regarding the timing of intubation in patients with COVID-19 pneumonia with ARDS. The questions were formulated based on the literature review. The draft questionnaire was sent to three critical care physicians not involved in the study, the feedback was taken and relevant changes made in the final questionnaire.

\section{Data Collection}

The questionnaire was uploaded in a web-based platform, after which it was circulated among critical care physicians. Critical Care physicians from India, Singapore, Canada and the United Kingdom have taken part in the survey. Consent was taken from each respondent before he/she took part in the survey. Intensivists, Anesthesiologists \& Physicians were included in the survey. The questionnaire included multiple choice questions. Participants were allowed to enter their own responses wherever it was appropriate. A responder was allowed to take the survey only once; repeated attempts were not allowed. 


\section{Statistical Analysis}

Since there has been no previous study on this topic, it was impossible to calculate the sample size. The data collected through web platform were entered into Microsoft excel. The categorical variables were expressed as frequency (percentage). A chi-square test was used to determine the correlation between respondents' demographic profiles with the timing of intubation in COVID-19 patients. The statistical analysis was performed by using statistical software IBM SPSS version 25.0.

\section{Results}

The study was conducted from 10th of June 2020 to 31st of August 2020. 292 doctors took part in the survey after giving their consent. 172 (58\%) were intensivist, 84 (28.8\%) were anesthesiologist and rest belonged to other specialities. $75.3 \%$ of the participants had seen more than 100 cases of COVID in their practice. The responses to various questions are provided in Table 1.Table 1240 (82.2\%) doctors felt COVID ARDS is different from other typical ARDS. Nearly two thirds of the respondents felt that patient self-inflicted lung injury (P-SILI) is a clinical entity. $34.2 \%$ felt that delayed intubation was associated with higher survival or higher mortality was seen with earlier intubation. $82.2 \%$ felt that intubation increased the risk of developing Nosocomial pneumonia. $46.8 \%$ of clinicians agreed that higher mortality in COVID19 caused due to disease process and $28.8 \%$ were agreed due to P-SILI or high transpulmonary pressure. Figure 1

In subgroup analysis, it was found that around $51.2 \%$ of intensivist had seen more than 100 severe pneumonia patients as compared to the anesthesiologist (14.3\%) and others (11.1\%). $83.7 \%$ of intensivists and $81 \%$ of anesthesiologist believed that COVID 19 ARDS is different from another form of ARDS. Likely, most of the anesthesiologists (66.7\%) and intensivists (72.1\%) agreed that P-SILI could happen in COVID 19 ARDS patients. Almost $97.7 \%$ of intensivists and $76.2 \%$ of anesthesiologists agreed that HFNC is valuable and should be used when patient develops hypoxia, if available ( $p$ value $=0.008$ ). Among those who agreed with HFNC as a modality during hypoxia early in the management, $47.6 \%$ of the intensivists and $43.7 \%$ of the anesthesiologists would opt for invasive mechanical ventilation. The rest preferred noninvasive mechanical ventilation (NIV) as the next step in managing, upon HFNC failure. However, among those who did not think that HFNC would be of any value in patients with worsening hypoxia, most of them preferred invasive mechanical ventilation. Very few participants $(14.3 \%$ of the anesthesiologists, $32.6 \%$ of the intensivists and $44.4 \%$ of the others) thought that NIV could increase the P-SILI risk. Regarding nosocomial infections, around $85.7 \%$ of anesthesiologists, $76.7 \%$ intensivists, and all other participants felt intubation might cause nosocomial infection. Around $42.9 \%$ of anesthesiologists believed that patient is more likely to survive if invasive mechanical intubation is delayed or avoided, while $41.9 \%$ of intensivists believed the contrary. Regarding weaning; and reintubation in extubated patients, most of the participants agreed that weaning needs a very cautious approach. They were not of the view that the rate of re-intubation is higher in extubated patients. Majority of the participants (95.2\% anesthesiologists, $83.7 \%$ intensivists and $66.7 \%$ others) had not experienced post-extubation stridor in COVID 19 patients when compared to other diseases. Table 2 


\section{Discussion}

COVID 19 Is a new disease and a pandemic, it has affected almost every human on Earth either directly or indirectly.[5] Research in the field is ever increasing. There has been considerable confusion regarding the timing of intubation in COVID 19. Gattinoni et al.[6] in 2020, published a letter to the editor, where they mentioned that patients with COVID 19 acute respiratory distress generally presented with hypoxemia, unusual lung compliance and preserved lung gas volume in CT thorax imaging. That may lead to a substantial increase in minute ventilation and respiratory drive.[6] The increased respiratory drive present may amplify the risk of lung injury through P-SILI. If oxygen therapy, HFNC and NIV are unable to match or compensate for these increased respiratory efforts; patients may still need invasive mechanical ventilation even after resolution of hypoxemia.[6] This statement was also supported by observation obtained from hundreds of patients in Italy and the United Kingdom. In contrast, Tobin et al.[7] criticized that P-SILI is a recent invention and there was not sufficient literature in support. However, a recently published article showed a reduction in median oesophageal pressure in those patients of COVID 19 ARDS, who were on NIV support and had improved chest radiology.[8, 9] So, the confusion regarding the timing of intubation and invasive mechanical ventilation in Covid19 ARDS patients still lingers on.

Our survey found out that most physicians treating COVID 19 patients, believe that COVID ARDS is different from typical ARDS, thus it makes them decide differently regarding the indications for intubation. $56.2 \%$ of all the respondents were of the view that mortality in COVID 19 ARDS is higher when compared to other forms of ARDS. Chiumello et al.[10] in a study where they compared the CT findings of COVID 19 ARDS with historical controls found COVID 19 ARDS to be a subset of "typical" ARDS with better compliance, especially in early stages. Considering the COVID 19 ARDS population is very homogeneous compared to a heterogeneous population of typical ARDS, some differences were expected between the two populations. Overall, there was however not much difference and the mortality rates in the study were also similar in the two groups. The differences that were observed did not affect the decision for intubation. They primarily suggested some differences in the ventilatory settings and avoidance of recruitment maneuvers.

$67.1 \%$ of respondents agreed on P-SILI, even though it's something whose existence is disputed. It's a form of lung injury which has been documented quite recently though there have been some studies in late 1980s suggesting about it.[11] Nearly $90 \%$ of the respondents agreed on use of spontaneous awake proning in case of hypoxia and also in for of using high flow nasal cannula (HFNC) if the hypoxia persisted. $56.3 \%$ preferred to give a trial of non-invasive ventilation (NIV) if HFNC was unavailable or failed. $47.9 \%$ of these were unsure about the impact of NIV on development of P-SILI. Many have shared cases where patients on NIV developed subcutaneous emphysema and pneumothoraces.

Around $30 \%$ of patients with acute hypoxemic respiratory failure are treated with non-invasive ventilatory support. P-SILI can be reduced by use of high PEEP, but it is difficult to provide through NIV due to higher amount of leaks and interruptions in NIV as during feeding, patient discomfort and position changes. NIV failure is associated with mortality rates around $50 \%$ which in our opinion is usually because of delayed 
intubation.[12] This is mainly because of prolonged exposure of injured diseased lungs to high tidal volumes and trans-pulmonary pressure swings.[13] Treatment failure with NIV is more expected in patients with more severe disease: Pao2/FiO2 < $200 \mathrm{mmHg}$ before treatment and higher SAPS II score (> 35) are associated with higher risk of being intubated.[13] The real dilemma is how to know patient is going into NIV failure. There have been many proposed ways to decide on NIV failure like swing in Pes (Esophageal pressure - a surrogate of $\mathrm{PL}$ ) or tidal volume more than $9-9.5 \mathrm{ml} / \mathrm{kg}$. HACOR scoring which takes in to account heart rate, $\mathrm{GCS}, \mathrm{pH}, \mathrm{P} / \mathrm{f}$ ratio and respiratory rate can also be used for this purpose. [14] For patients undergoing HFNC, a simple ROX index (ratio of SpO2/FiO2 to respiratory rate, evaluated continuously during treatment) has been tested and validated to predict treatment success and failure. Patients with ROX Index $>4.88$ after two hours of treatment are likely to avoid intubation, while those with a ROX $<2.85,<3.47$ and $<3.85$ after two, six and 12 hours of HFNC are at high risk of treatment failure and the need for endotracheal intubation and invasive mechanical ventilation.[15]

Nosocomial Pneumonia is a major complication in ICU patients.[16] VAP rates have not come down in recent times despite adherence to various prevention bundles. Most of the clinicians in our survey; in spite of their doubts in NIV to cause P-SILI, still persisted with it as they feared higher incidences of ventilator associated pneumonia (VAP) and other nosocomial infections if the patient got intubated. This fear was more driven due to shortage of adequately trained staffs in COVID ICUs. There are limited studies looking into the incidence of hospital acquired pneumonia in COVID ARDS patients. Whether use of NIV reduces risk of nosocomial pneumonia or not is not yet clear as per the available literature. The present of an endotracheal tube is expected to increase the risk of biofilm formation and colonization of the airways. [17] Diagnosis of VAP is very difficult in a patient of ARDS. These factors make it difficult for us to make a conclusion whether NIV is protective or not in development of VAP.

\section{Limitations}

Our survey also has many limitations. The sample size is small and even though it included doctors from various countries it may not be reflective of the opinion of all the doctors. Since COVID 19 is a recent disease the participants exposure to various literature available may have been different and possibly past experience from other ARDS may have influenced their opinions.

\section{Conclusion}

Our survey concluded that, there was confusion among the practicing physicians regarding timing of intubation and initiation of invasive mechanical ventilation. Most of the clinicians believed that considering intubation earlier in the course of the disease may increase the mortality and risk of nosocomial infection. Further study of various management protocols and patient outcomes would gradually provide a clearer picture regarding initiation of invasive mechanical ventilation and its effects and adverse effects.

\section{Declarations}




\section{Ethical Approval and Consent to participate}

Ethical approval was taken from Institutional Ethics Committee of IMS and SUM Hospital, SOA deemed to be University, Bhubaneswar before starting of the study. Individual consent was taken from individual participants using google forms.

\section{Consent for Publication}

Consent for publication was obtained from all participants. Written informed consent was waived for all participants with emerging infectious diseases.

\section{Availability of supporting data}

Not applicable

\section{Competing of interest}

Authors declare to have no competing of interest.

\section{Funding}

Not applicable

\section{Authors' contributions}

Study concept and design: S.B.M, S.S.

Acquisition, analysis, or interpretation of data: All Authors

Drafting of the manuscript:S.B.M, S.K.P

Critical revision of the manuscript for important intellectual content: S.B.M, S.S.

Statistical analysis: S.K.P

Study supervision: S.B.M, S.S., R.K.

\section{Acknowledgement}

Not applicable

\section{References}

1. World Health Organization (WHO). WHO Director-General's opening remarks at the media briefing on COVID-19-11 March 2020. WHO Dir Gen speeches. 2020; March:4. https://www.who.int/directorgeneral/speeches/detail/who-director-general-s-opening-remarks-at-the-media-briefing-on-covid-19- 
-11-march-2020\%0Ahttps://www.who.int/dg/speeches/detail/who-director-general-s-openingremarks-at-the-media-briefing-on-covid-19.

2. WHO. Clinical management of severe acute respiratory infection when COVID-19 is suspected (v1.2). WHO Rep. 2020;:1-21. https://www.who.int/publications-detail/clinical-management-of-severeacute-respiratory-infection-when-novel-coronavirus-(ncov)-infection-is-suspected.

3. Alhazzani W, Møller MH, Arabi YM, Loeb M, Gong MN, Fan E, et al. Surviving Sepsis Campaign: guidelines on the management of critically ill adults with Coronavirus Disease 2019 (COVID-19). Intensive Care Med. 2020;46:854-87.

4. Gattinoni L, Chiumello D, Caironi P, Busana M, Romitti F, Brazzi L, et al. COVID-19 pneumonia: different respiratory treatments for different phenotypes? Intensive Care Med. 2020;46:1099-102. doi:10.1007/s00134-020-06033-2.

5. Harapan H, Itoh N, Yufika A, Winardi W, Keam S. Coronavirus disease 2019 (COVID-19): A literature review. 2020; January.

6. Gattinoni L, Marini JJ, Busana M, Chiumello D, Camporota L. Spontaneous breathing, transpulmonary pressure and mathematical trickery. Ann Intensive Care. 2020;10:1-2. doi:10.1186/s13613-020-00708-1.

7. Tobin MJ, Laghi F, Jubran A. Caution about early intubation and mechanical ventilation in COVID-19. Ann Intensive Care. 2020;10:4-6. doi:10.1186/s13613-020-00692-6.

8. Yoshida T, Fujino Y, Amato MBP, Kavanagh BP. Fifty years of research in ards spontaneous breathing during mechanical ventilation risks, mechanisms, and management. Am J Respir Crit Care Med. 2017;195:985-92.

9. Yoshida T, Uchiyama A, Matsuura N, Mashimo T, Fujino Y. The comparison of spontaneous breathing and muscle paralysis in two different severities of experimental lung injury. Crit Care Med. 2013;41:536-45.

10. Chiumello D, Busana M, Coppola S, Romitti F, Formenti P, Bonifazi M, et al. Physiological and quantitative CT-scan characterization of COVID-19 and typical ARDS: a matched cohort study. Intensive Care Med. 2020;46:2187-96. doi:10.1007/s00134-020-06281-2.

11. Mascheroni D, Kolobow T, Fumagalli R, Moretti MP, Chen V, Buckhold D. Acute respiratory failure following pharmacologically induced hyperventilation: an experimental animal study. Intensive Care Med. 1988;15:8-14.

12. Nguyen T, Hoskote S. Patient Self-Inflicted Lung Injury: the Case Against Early Spontaneous Ventilation in Ards. Chest. 2019;156:A1279. doi:10.1016/j.chest.2019.08.1150.

13. Carteaux G, Millán-Guilarte T, De Prost N, Razazi K, Abid S, Thille AW, et al. Failure of Noninvasive Ventilation for de Novo Acute Hypoxemic Respiratory Failure: Role of Tidal Volume*. Crit Care Med. 2016;44:282-90.

14. Marini JJ, Hotchkiss JR, Broccard AF. Bench-to-bedside review: Microvascular and airspace linkage in ventilator-induced lung injury. Crit Care. 2003;7:435-44. 
15. Grieco DL, Menga LS, Eleuteri D, Antonelli M. Patient self-inflicted lung injury: Implications for acute hypoxemic respiratory failure and ARDS patients on non-invasive support. Minerva Anestesiol. 2019;85:1014-23.

16. Udobi KF, Childs E, Touijer K. Acute respiratory distress syndrome. Am Fam Physician. 2003;67:31522.

17. Bertoni M, Spadaro S, Goligher EC. Monitoring Patient Respiratory Effort during Mechanical Ventilation: Lung and Diaphragm-Protective Ventilation. Crit Care. 2020;24.

\section{Table}

Table 1. Responses to questions. 


\begin{tabular}{|c|c|c|c|}
\hline & & Count & $\mathrm{N} \%$ \\
\hline \multirow[t]{3}{*}{ You are a/an } & Anesthesiologist & 84 & $28.8 \%$ \\
\hline & Intensivist & 172 & $58.9 \%$ \\
\hline & Others & 36 & $12.3 \%$ \\
\hline \multirow{4}{*}{$\begin{array}{l}\text { How many cases of severe COVID-19 pneumonia } \\
\text { (Requiring oxygen or greater support) have you managed? }\end{array}$} & $<10$ & 72 & $24.7 \%$ \\
\hline & $<100$ & 116 & $39.7 \%$ \\
\hline & $<500$ & 88 & $30.1 \%$ \\
\hline & $>500$ & 16 & $5.5 \%$ \\
\hline \multirow{2}{*}{$\begin{array}{l}\text { Do you believe that COVID-19 ARDS is different from other } \\
\text { causes of ARDS }\end{array}$} & Yes & 240 & $82.20 \%$ \\
\hline & No & 52 & $17.80 \%$ \\
\hline \multirow{2}{*}{$\begin{array}{l}\text { Do you think patient induced self-inflicted injury (P-SIU) } \\
\text { can happen? }\end{array}$} & Yes & 196 & $67.10 \%$ \\
\hline & No & 96 & $32.90 \%$ \\
\hline \multirow{2}{*}{$\begin{array}{l}\text { Do you believe that spontaneous prone is of value in } \\
\text { COVID-19 ARDS? }\end{array}$} & Yes & 260 & $89.0 \%$ \\
\hline & No & 32 & $11.0 \%$ \\
\hline \multirow{2}{*}{$\begin{array}{l}\text { Do you believe that COVID-19 ARDS is different fromother } \\
\text { causes of ARDS }\end{array}$} & Yes & 240 & $82.2 \%$ \\
\hline & No & 52 & $17.8 \%$ \\
\hline \multirow{2}{*}{$\begin{array}{l}\text { Do you think patient induced self-inflicted injury (P-SIU) } \\
\text { can happen? }\end{array}$} & Yes & 196 & $67.1 \%$ \\
\hline & No & 96 & $32.9 \%$ \\
\hline \multirow{2}{*}{$\begin{array}{l}\text { Do you believe that spontaneous prone is of value in } \\
\text { COVID-19 ARDS? }\end{array}$} & Yes & 260 & $89.0 \%$ \\
\hline & No & 32 & $11.0 \%$ \\
\hline \multirow{2}{*}{$\begin{array}{l}\text { Do you believe that high flow nasal cannula (HFNC) is of } \\
\text { value in COVID-19 ARDS if there is fall in saturation? }\end{array}$} & Yes & 268 & $91.8 \%$ \\
\hline & No & 24 & $8.2 \%$ \\
\hline \multirow[t]{2}{*}{ If $u$ think HFNC is of value, what will you do if it fails } & Intubation & 116 & $43.3 \%$ \\
\hline & NIV trial & 152 & $56.7 \%$ \\
\hline \multirow{2}{*}{$\begin{array}{l}\text { If } u \text { think HFNC is of no value, what will you do if patients } \\
\text { hypoxia worsens }\end{array}$} & Intubation & 16 & $66.7 \%$ \\
\hline & NIV & 8 & $33.3 \%$ \\
\hline \multirow[t]{3}{*}{ Do you think NN increases the risk of P-SILI? } & Yes & 84 & $28.8 \%$ \\
\hline & No & 68 & $23.3 \%$ \\
\hline & May be & 140 & $47.9 \%$ \\
\hline \multirow{3}{*}{$\begin{array}{l}\text { Do you think Intubation increases the risk of Nosocomial } \\
\text { Infection }\end{array}$} & Yes & 240 & $82.2 \%$ \\
\hline & No & 16 & $5.5 \%$ \\
\hline & may be & 36 & $12.3 \%$ \\
\hline \multirow{3}{*}{$\begin{array}{l}\text { In COVID } 19 \text { the longer I can avoid intubation, more } \\
\text { chance my Patient will survive. }\end{array}$} & Yes & 100 & $34.2 \%$ \\
\hline & No & 108 & $37.0 \%$ \\
\hline & may be & 84 & $28.8 \%$ \\
\hline \multirow{3}{*}{$\begin{array}{l}\text { In COVID } 19 \text { the sooner I intubate, more chance my Patient } \\
\text { will survive }\end{array}$} & Yes & 60 & $20.5 \%$ \\
\hline & No & 168 & $57.5 \%$ \\
\hline & May be & 64 & $21.9 \%$ \\
\hline \multirow{3}{*}{$\begin{array}{l}\text { Mortality in COVID } 19 \text { ARDS is higher compared to other } \\
\text { causes of ARDS? }\end{array}$} & Yes & 164 & $56.2 \%$ \\
\hline & No & 76 & $26.0 \%$ \\
\hline & may be & 52 & $17.8 \%$ \\
\hline \multirow[t]{2}{*}{$\begin{array}{l}\text { In your opinion, are weaning and spontaneous breathing } \\
\text { trials in COVID -19different from other diseases? }\end{array}$} & $\begin{array}{l}\text { Yes, this needs avery } \\
\text { cautious approach }\end{array}$ & 172 & $58.9 \%$ \\
\hline & $\begin{array}{l}\text { No, it is similar to my routine } \\
\text { practice }\end{array}$ & 120 & $41.1 \%$ \\
\hline \multirow{2}{*}{$\begin{array}{l}\text { Did you experience high re-intubation rates in extubated } \\
\text { COVID-19 compared to other diseases? }\end{array}$} & Yes & 88 & $30.1 \%$ \\
\hline & No & 204 & $69.9 \%$ \\
\hline \multirow{2}{*}{$\begin{array}{l}\text { Did you experience a high incidence of post-extubation } \\
\text { stridor in COVID-19compared to other diseases? }\end{array}$} & Yes & 44 & $15.1 \%$ \\
\hline & No & 248 & $84.9 \%$ \\
\hline
\end{tabular}

Table 2. Subgroup Analysis 


\begin{tabular}{|c|c|c|c|c|c|c|c|c|}
\hline & & \multicolumn{6}{|c|}{ You are a/an } & \multirow[b]{3}{*}{ p value } \\
\hline & & \multicolumn{2}{|c|}{ Anesthesid } & \multicolumn{2}{|c|}{ Intersivist } & \multicolumn{2}{|c|}{ Others } & \\
\hline & & Count & $\mathrm{N} \%$ & Count & $\mathrm{N} \%$ & Count & $\mathrm{N} \%$ & \\
\hline \multirow{4}{*}{$\begin{array}{l}\text { How many cases of severe COVD-19 } \\
\text { pneumonia (Requiring oxygen or greater } \\
\text { support) have you managed? (Approximately) }\end{array}$} & $<10$ & 36 & $42.9 \%$ & 12 & $7.0 \%$ & 36 & $68.7 \%$ & 0.000 \\
\hline & $<100$ & 38 & $42.9 \%$ & 72 & $41.9 \%$ & 8 & $22.2 \%$ & \\
\hline & $<500$ & 12 & $14.3 \%$ & 78 & $44.2 \%$ & 0 & $0.0 \%$ & \\
\hline & $>500$ & 0 & $0.0 \%$ & 12 & $7.0 \%$ & 4 & $11.1 \%$ & \\
\hline \multirow{2}{*}{$\begin{array}{l}\text { Do you believe that COMD-19 ARDS is } \\
\text { different from other causes of ARDS }\end{array}$} & Yes & 68 & $81.0 \%$ & 144 & $83.7 \%$ & 28 & $77.8 \%$ & 0.900 \\
\hline & No & 16 & $19.0 \%$ & 28 & $16.3 \%$ & 8 & $22.2 \%$ & \\
\hline \multirow{2}{*}{$\begin{array}{l}\text { Do you think patient induced self-inflicted injury } \\
\text { (P-SILI) can happen? [lt is barot auma occurring } \\
\text { in patients who are breathing spontaneous ly] }\end{array}$} & Yes & 56 & $68.7 \%$ & 124 & $72.1 \%$ & 16 & $44.4 \% 6$ & 0.275 \\
\hline & No & 28 & $33.3 \%$ & 48 & $27.9 \%$ & 20 & $55.6 \%$ & \\
\hline \multirow{2}{*}{$\begin{array}{l}\text { Do you believe that s pontaneous prone is of } \\
\text { value in COMD-19 ARDS? }\end{array}$} & Yes & 78 & $90.5 \%$ & 156 & $90.7 \%$ & 28 & $77.8 \%$ & 0.513 \\
\hline & No & 8 & $9.5 \%$ & 18 & $9.3 \%$ & 8 & $22.2 \%$ & \\
\hline \multirow{2}{*}{$\begin{array}{l}\text { Do you believe that high flow nas al cannula } \\
\text { (HFNC) is of value in COMD-19 ARDS if there } \\
\text { is fall in saturation? }\end{array}$} & Yes & 64 & $78.2 \%$ & 168 & $97.7 \%$ & 38 & $100.0 \%$ & 0.008 \\
\hline & No & 20 & $23.8 \%$ & 4 & $2.3 \%$ & 0 & $0.0 \%$ & \\
\hline \multirow{2}{*}{$\begin{array}{l}\text { If } u \text { think HFNC is of value, what will you do if it } \\
\text { fails }\end{array}$} & Intubation & 28 & $43.7 \%$ & 80 & $47.6 \%$ & 8 & $22.2 \%$ & 0.020 \\
\hline & NIVtrial & 38 & $58.2 \%$ & 88 & $52.4 \%$ & 28 & $77.8 \%$ & \\
\hline \multirow{2}{*}{\multicolumn{2}{|c|}{$\begin{array}{l}\text { If } u \text { think HFNC is of no value, what will you do if Intubation } \\
\text { patients hypoxia worsens }\end{array}$}} & 12 & $60.0 \%$ & 4 & $100.0 \%$ & 0 & $0.0 \%$ & 0.041 \\
\hline & & 8 & $40.0 \%$ & 0 & $0.0 \%$ & 0 & $0.0 \%$ & \\
\hline \multirow[t]{3}{*}{ Do you think NN increases the risk of P-SIL? } & Yes & 12 & $14.3 \%$ & 58 & $32.6 \%$ & 8 & $44.4 \%$ & 0.189 \\
\hline & No & 28 & $33.3 \%$ & 28 & $16.3 \%$ & 12 & $33.3 \%$ & \\
\hline & May be & 44 & $52.4 \%$ & 88 & $51.2 \%$ & 8 & $22.2 \%$ & \\
\hline \multirow{3}{*}{$\begin{array}{l}\text { Do you think Intubation increases the risk of } \\
\text { Nosocomial Infection }\end{array}$} & Yes & 72 & $85.7 \%$ & 132 & $76.7 \%$ & 38 & $100.0 \%$ & 0.558 \\
\hline & No & 4 & $4.8 \%$ & 12 & $7.0 \%$ & 0 & $0.0 \%$ & \\
\hline & Maybe & 8 & $9.5 \%$ & 28 & $16.3 \%$ & 0 & $0.0 \%$ & \\
\hline \multirow{3}{*}{$\begin{array}{l}\text { In COVD } 19 \text { the longer I can avoid intubation, } \\
\text { more chance my Patient will survive. }\end{array}$} & Yes & 38 & $42.9 \%$ & 44 & $25.6 \%$ & 20 & $55.8 \%$ & 0.344 \\
\hline & No & 24 & $28.8 \%$ & 72 & $41.9 \%$ & 12 & $33.3 \%$ & \\
\hline & May be & 24 & $28.6 \%$ & 58 & $32.6 \%$ & 4 & $11.1 \%$ & \\
\hline \multirow{3}{*}{$\begin{array}{l}\text { In COVD } 19 \text { the sooner I intubate, more chence } \\
\text { my Patient will survive }\end{array}$} & Yes & 16 & $19.0 \%$ & 44 & $25.6 \%$ & 0 & $0.0 \%$ & 0.300 \\
\hline & No & 52 & $61.9 \%$ & 96 & $55.8 \%$ & 20 & $55.6 \% 6$ & \\
\hline & may be & 16 & $19.0 \%$ & 32 & $18.6 \%$ & 16 & $44.4 \%$ & \\
\hline \multirow{3}{*}{$\begin{array}{l}\text { Mortality in COMD } 19 \text { ARDS is higher comper ed } \\
\text { to other causes of ARDS? }\end{array}$} & Yes & 38 & $42.9 \%$ & 104 & $60.5 \%$ & 24 & $66.7 \%$ & 0.149 \\
\hline & No & 20 & $23.8 \%$ & 52 & $30.2 \%$ & 4 & $11.1 \%$ & \\
\hline & May be & 28 & $33.3 \%$ & 16 & $9.3 \%$ & 8 & $22.2 \%$ & \\
\hline \multirow{2}{*}{$\begin{array}{l}\text { In your opinion, are weaning and spontaneous } \\
\text { breathing trials in COMD -19different from other } \\
\text { diseases? }\end{array}$} & $\begin{array}{l}\text { Yes, this needs a } \\
\text { very cautious } \\
\text { approach } \\
\text { No, it is similar to }\end{array}$ & 58 & $68.7 \%$ & 92 & $53.5 \%$ & 24 & $68.7 \%$ & 0.531 \\
\hline & $\begin{array}{l}\text { my routine } \\
\text { practice }\end{array}$ & 28 & $33.3 \%$ & 80 & $46.5 \%$ & 12 & $33.3 \%$ & \\
\hline $\begin{array}{l}\text { Did you experien ce high re-intubation rates in } \\
\text { extubated COVD-19 comper ed to other }\end{array}$ & Yes & 20 & $23.8 \%$ & 64 & $37.2 \%$ & 4 & $11.1 \%$ & 0.227 \\
\hline diseases? & No & 64 & $78.2 \%$ & 108 & $62.8 \%$ & 32 & $88.9 \%$ & \\
\hline $\begin{array}{l}\text { Did you experien oe a high incidence of post- } \\
\text { extubation stridor in COMD-19compar ed to }\end{array}$ & Yes & 4 & $4.8 \%$ & 28 & $16.3 \%$ & 12 & $33.3 \%$ & 0.126 \\
\hline other diseases? & No & 80 & $95.2 \%$ & 144 & $83.7 \%$ & 24 & $66.7 \%$ & \\
\hline
\end{tabular}

\section{Figures}


What do you think is the cause of higher mortality in COVID-19?

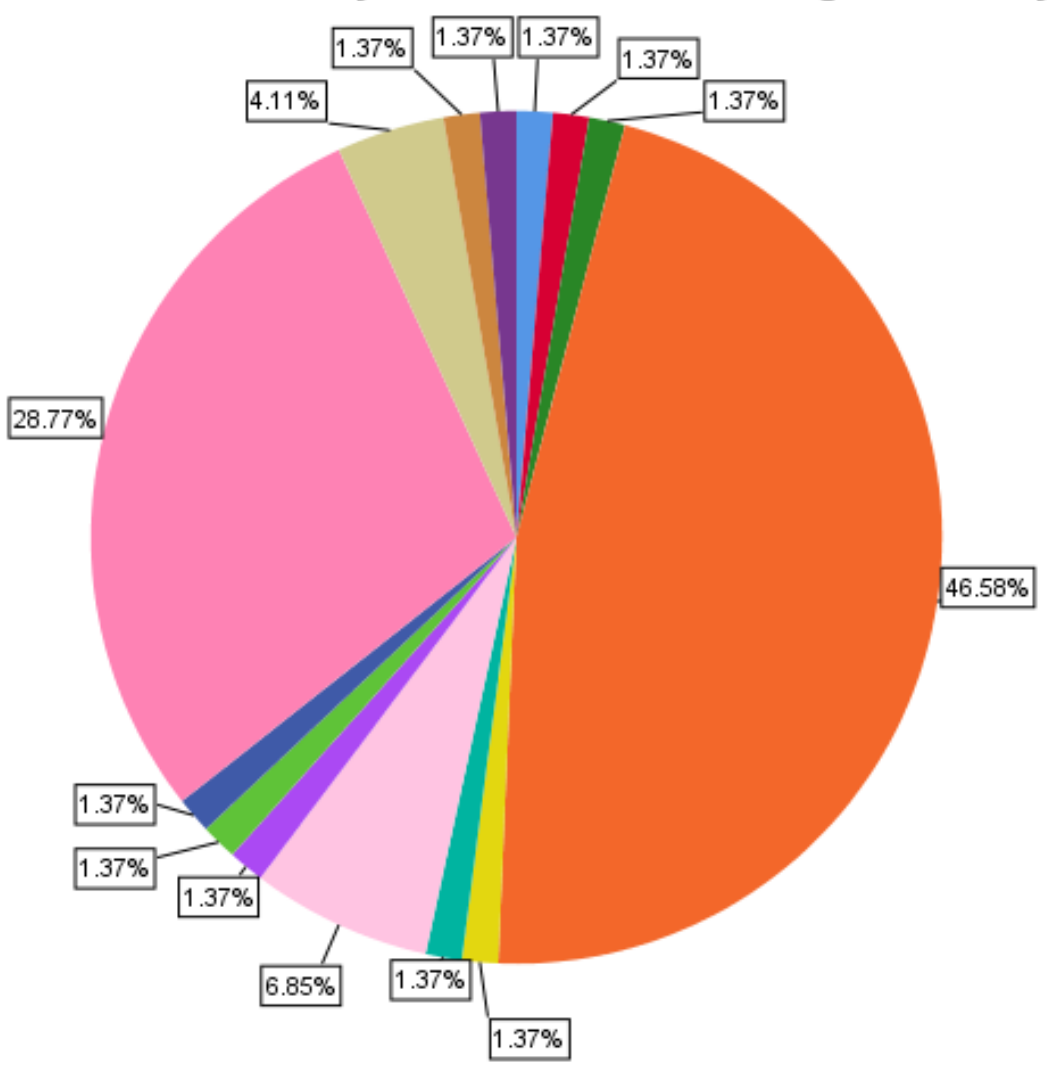

Coagulopathy

Decreased care

Delay in initiation of steroid and anticoagulant

Disease process

Hypercoagulability \& post ards fibrosis

Hyperthrombotic state

I dont think mortality is high

Late diagnosis leads to late onset of treatment

MODS

Prothrombotic states with higher incidence of DVT, PE, MI and stroke

P-SILI / Lung strain / high transpulmonary pressure Secondary infections related intubation

Thrombotic adverse events

Too many immunomodulators

Figure 1

Causes of higher mortality in COVID-19. 